\title{
Impact of Legal Education on the Development of Space Law
}

\section{Olena Fatkhutdinova}

\author{
Doctor of Philosophical Sciences, Professor, \\ Honored Lawyer of Ukraine, Dean of the Faculty of Law, \\ Kyiv University of Tourism, Economics and Law \\ (Kyiv, Ukraine) \\ E-mail: mfkoorg@gmail.com
}

In the contemporary world, the influence of legal education on the development of space law is given particular attention. Review of scientific papers showed the relevance of the impact of legal education in the development of space law. The purpose of the study is to consider the peculiarities of the influence of legal education on the development of space law. The author reviewed the structure of the activity direction of legal education, which deepens the study and further development of space law. The author has proved that knowledge of space law in domestic and interstate activities provides a deeper understanding of the roles space, technology and law play in the globalized world. Knowledge of space law and the development of legal education in Ukraine contributes to the establishment of international cooperation in the exploration and use of space.

Keywords: space law; legal education; activity approach; legal activity.

\section{Вплив правової освіти на розвиток космічного права}

\section{Фатхутдінова, Олена Василівна}

Доктор філософських наук, професор, Заслужений юрист України, декан юридичного факультету, Київський університет туризму, економіки і права

(Київ, Україна)

\begin{abstract}
У сучасному світі впливу правової освіти на розвиток космічного права приділяється особливо пильна увага. Розгляд наукових робіт засвідчив актуальність проблеми впливу правовоі освіти на розвиток космічного права. Метою дослідження є розгляд особливостей впливу правової освіти на розвиток космічного права. Автор розглянула структуру діяльнісної направленості правової освіти, щчо поглиблює вивчення і подальшу розробку космічного права. Автором доведено, щңо знання космічного права у внутрішньодержавній і міждержавній діяльності забезпечує глибше розуміння ролей, які космос, технології та право грають у глобалізованому
\end{abstract}

(C) Fatkhutdinova, Olena, 2018 
світі. Знання космічного права та розвиток правової освіти в Украйні сприяє налагодженню міжнародній співпраці в дослідженні та використанні космосу.

Ключові слова: космічне право; правова освіта; діяльнісний підхід; правова діяльність.

Received: February 1, 2018; accepted: February 27, 2018

Advanced Space Law, Volume 1, 2018: 42-49.

https://doi.org/10.29202/asl/2018/1/5

\section{Вступ}

У сучасному світі впливу правової освіти на розвиток космічного права приділяється особливо пильна увага. В 2014 році під егідою Організації Об'єднаних Націй вийшла «Програма викладання космічного права» («Education Curriculum on Space Law»). Програма складається з чотирьох модулів [Education, 2014]:

1. Модуль 1. Основні поняття міжнародного права та космічного права;

2. Модуль 2. Міжнародне право та інші нормативні акти, що застосовуються до дистанційного зондування, географічних інформаційних систем, супутникової метеорології та глобальної кліматичної діяльності;

3. Модуль 3. Супутниковий зв'язок та чинне міжнародне право, а також інші нормативні акти;

4. Модуль 4. Глобальні супутникові системи навігації та чинне міжнародне право, а також інші нормативні акти.

В програмі зазначається, що «Розбудова потенціалу, підготовка кадрів і освіта в космічному праві мають першорядне значення для національних, регіональних і міжнародних зусиль для подальшого розвитку космічної діяльності, зокрема, щодо сприяння більш широкому розумінню і прийняттю міжнародно-правової бази, що регулює проведення космічної діяльності» [Education, 2014: 4].

Заслуговує на увагу стаття Галини Берегової «Філософія єдності та розвитку гармонії як варіант антропокосмічного світогляду». У статті авторка наголошує на цілісності людини і простору з точки зору сучасних цивілізаційних аспектів і ноосферного вектора генерації людства [Berehova, 2017]. У статті «Управління суспільством майбутнього: нові тенденції у підготовці державних службовців в Україні» Раїса Науменко підкреслює необхідність систематичного розвитку державними службовцями свого професійного ресурсу, який базується на творчості. Тільки саморозвиток і створення умов для саморозвитку державних службовців є потужним джерелом сучасного менеджменту [Naumenko, 2017]. У статті Василя Фатхутдінова та Олега Базалука «Значення технологій нейропрограммування мозку в національних і регіональних стратегіях безпеки» розглядається історія формування ключових технологій нейропрограмування людського мозку. Автори доводять, що зміни у світогляді суспільства зумовлені можливостями та якістю ключових технологій нейропрограмування, які використовує суспільство, перш за все освітніх технологій [Fatkhutdinov \& Bazaluk, 2018]. Роман Олексенко та Лідія Фьодорова розглядають можливості освітніх технологій в першій космічній державі «Асгардія», що створена на засадах сучасного міжнародного космічного права [Oleksenko \& Fedorova, 2017]. 
Таким чином, розгляд наукових робіт засвідчує актуальність проблеми впливу правової освіти на розвиток космічного права. Метою нашого дослідження $\epsilon$ розгляд особливостей впливу правової освіти на розвиток космічного права. Ми розглянемо структуру діяльнісної направленості правової освіти.

\section{Виклад основного матеріалу}

Важливим етапом у розвитку ідей гуманізації правової освіти в Україні є умова реалізації діяльнісної направленості правової освіти. Спираючись на дослідження Олександра Новікова під діяльнісною направленістю правової освіти ми розуміємо наступне [Новиков, 2008]:

I. Зв'язок теоретичних знань студентів з їх практичними потребами, ичіннісними оріснтаціями.

Як зазначає у дисертаційному дослідженні Патімат Гаджиєва: «Аналіз науково-педагогічної літератури показує, що правову освіту особистості не слід розглядати тільки 3 позиції іiі профілактичної ролі у справі боротьби з правопорушеннями у державі. Правову освіту в школі слід розуміти у більш широкому значенні — як необхідну (хоча і недостатню) умову при набутті досвіду демократичної культури [Гаджиєва, 2005: 15]».

Велику увагу у правовій освіті слід приділяти практичному засвоєнню матеріалу. Патімат Гаджиєва виділяє наступні цінності та пріоритети правової культури, сутність правової освіти учнів [Гаджиєва, 2005]:

- знання особою своїх прав та свобод;

- вміння реалізовувати їх, не порушуючи права та свободу інших людей;

- здатність відповідати за свої вчинки та за свій вибір;

- критичне та одночасно перетворююче відношення до реального життя;

- здатність застосовувати на практиці отримані правові знання.

У навчальному процесі особливо слід звернути увагу на практику, на те, щоб практика не була формальною галочкою в освітньому процесі, а в повному обсязі забезпечувала залучення студента-юриста (коли ми говоримо про вищу юридичну освіту) 3 першого курсу навчання в спеціалізоване середовище, наприклад, у особливість надання юридичних послуг.

Практика повинна систематизувати теоретичні знання студентів, отримані від викладачів та вчити застосовувати їх у повсякденній діяльності. В європейській освіті практиці приділяють особливу увагу. Адже через практичний досвід не тільки самі студенти приходять до розуміння своєї майбутньої спеціальності і своєї готовності ії сумлінно виконувати, але й викладачі складають більш дієвий портрет майбутнього випускника.

Хотілося б звернути увагу на те, що практика правового навчання та виховання - це не просто присутність учнів та студентів у судовій, виконавчій, слідчій обстановці, це повноцінне залучення практикантів у професійну правову діяльність. Одна справа наочність та роз'яснення матеріалу, і зовсім інша — коли завдяки практиці студенти входять в образ слідчого, прокурора, судді, адвоката чи іншого суб'єкта правової діяльності та виконують покладені на дану особу обов'язки . Ще в 1924 р. в Гарвардській школі бізнесу дійшли до висновку, що для аспірантів неможливо створити підручники, які б поєднували у собі сучасну інформацію та практику. Тому до слухачів стали запрошувати топ-менеджерів провідних корпорацій, які стали пропонувати реальні ситуації, з котри- 
ми зіштовхнулися їх компанії, а слухачі повинні були запропонувати свої рішення виходів з цих ситуацій. Запропоновані варіанти слухачів порівнювали з рішеннями керівництва компанії, і потім відбувався аналіз всіх запропонованих варіантів рішень. Даний метод отримав назву «кейс-метод» (case-study, метод конкретних ситуацій). На сьогоднішній час кейс-метод застосовують в американських та європейських університетах. Кейс-метод дозволяє поєднувати теоретичне знання з практикою та з високим ступенем достовірності перевіряти готовність студентів-випускників до практичної діяльності.

Важливим способом формування в учнях та студентах повної уяви про вимоги прав особистості, виражені у нормах юридичної відповідальності, $\epsilon$ практика правового спілкування населення з правоохоронними органами у процесі правозахисної діяльності у зв'язку з порушенням прав і свобод. На думку деяких вчених, ця форма найбільш результативна з погляду правового виховання. Звідси формується найважливіше практичне завдання - домагатися від працівників правоохоронних органів точного і повного знання правових норм, що регламентують їх діяльність [Фіцула, 1997: 15]. Значення всебічного інформування населення про специфіку вимог прав особистості, виражених у нормах юридичної відповідальності, важко переоцінити. У результаті знання про них перевищують авторитет юридичної відповідальності, що виступає важливою передумовою ііі позитивної реалізації.

У проекті концепції розвитку вищої юридичної освіти в Україні в розділі «Вдосконалення навчального процесу» зазначаються такі позиції [Концепція розвитку, 2009]:

1. Збалансування співвідношення загальноправових дисциплін та юридичної казуїстики, як у межах бакалаврських, так і магістерських програм, а також обсяги наявних форм навчального процесу — аудиторної, позааудиторної та самостійної роботи, співвідношення яких має змінюватися вбік збільшення годин на практичні заняття залежно від року навчання;

2. Проведення практичної підготовки студентів-юристів в групах по 10-15 осіб з метою залучення всіх студентів до практичного вирішення ситуаційних завдань, кращого контролю щодо процесу вирішення ситуацій та об’єктивності оцінювання;

3. Впровадження форм, методів навчальних занять: розгляду реальних випадків правозастосування, проведення студентських дебатів, активного поширення імітаційних судових засідань та юридичних процедур регулятивного спрямування (отримання дозволів, реєстрація нерухомості, компаній, акцій тощо), участі у законотворчій роботі, проведення щорічних олімпіад з правознавства, консультування (інтерв'ювання) із запрошенням як арбітрів юристів-практиків, використання бінарних лекцій за участю викладача та юриста-практика;

4. Розробка комплексних навчальних курсів, що охоплюють практику виконання юридичних документів («юридичне письмо»), тактику та стратегію прийняття правових рішень, розробку та написання юридичних документів, елементи юридичної психології, етику та діяльність $з$ представництва інтересів громадян та юридичних осіб в судах, державних органах, органах місцевого самоврядування, риторику та судове мовлення.

5. Внесення змін та доповнень до наказів Міністерства освіти і науки України щодо юридичних клінік з метою включення курсу юридичної клініки до навчальних планів юридичних вищих навчальних закладів. Суттєве підвищення значення клінічної освіти у навчальному процесі, а саме: залучення студентів до юридич- 
них клінік як виду навчальної практики на усіх курсах навчання та зняття невиправданих вікових і кваліфікаційних обмежень; покращення матеріального та професійного кадрового забезпечення клінік (залучення на договірних засадах викладачів та юристів-практиків до керівництва, кураторства та консультування діяльності клінік), виділення годин навчальної та методичної роботи викладачів на роботу в юридичній клініці; розширення спільних програм юридичних клінік та неурядових організацій правозахисного спрямування; оцінювання роботи студентів у юридичних клініках, зокрема, у формі особистої звітності, та врахування цих результатів при нарахуванні навчальних кредитів та оцінюванні виробничої практики.

6. Збільшення обсягу практичної підготовки в магістратурі. Зокрема запровадження окремих курсів з ведення переговорів, медіації та договірної роботи, складання юридичних документів підвищеної складності (наприклад, касаційних скарг, меморандумів, матеріалів юридичної оцінки (due diligence), юридичних висновків, технік та методик юридичного аудиту тощо), тактики ведення справ у судах вищих інстанцій, міжнародному комерційному арбітражі, юридичної конфліктології та юридичної техніки, а також курсів державного управління, менеджменту в галузі, психології управління. Під час викладання зазначених курсів має віддаватися перевага практичним заняттям та рольовим іграм.

7. Розширення системи спеціалізованих факультативних курсів з комбінованим академічно-практичним складом викладачів та випробуваннями у вигляді участі у вирішенні реальних правових конфліктів (спорів, справ, ведення переговорів) під керівництвом куратора (як правило, висококваліфікованого юриста) із наступним заохоченням учасників таких програм;

8. Визначення базових вищих навчальних закладів та кафедр для запровадження постійно діючих наукових й науково-методичних семінарів для педагогічних, наукових і науково-педагогічних працівників;

II. Вдосконалення системи знань, які визначають діяльнісну направленість особиcmocmi.

Не всі знання, які отримані в навчальних закладах, сприяють діяльнісній направленості осіб, які навчаються. Адже коли ми розглядаємо визначну діяльнісну направленість майбутнього випускника-юриста, ми, насамперед, маємо на увазі ті предмети (іх комплекс), які з одного боку - роблять випускника-юриста фахівцем у своїй сфері діяльності, а з іншого боку — зацікавленою у професійному рості людиною, яка крім обов’язків знаходить у своїй роботі задоволення.

У цьому плані звертають на себе увагу дослідження російського економіста та аналітика Владислава Іноземцева, який наголошує на тому, що у майбутньому постіндустріальному суспільстві буде мати значення тільки творча активність особистості, яка проявляється у вільній та повноцінній реалізації внутрішніх потенціалів психіки у повсякденності [Иноземцев, 2000]. Із цього приводу В. Іноземцев пише: «Ми вважаємо можливим виділити три різних типи активності:

- інстинктивну діяльність людини на ранніх етапах ії прогресу;

- власна праця (labour);

- i творча діяльність (creativity, або creative work) як заперечення праці. 
Протиставляючи творчість праці, слід звертати увагу на специфічні форми людської взаємодії, адекватні творчості як типу діяльності. Як вже зазначалось, творчість пробуджується прагненням людини до самовдосконалення і його метою виступає сама особа. У цьому процесі головне значення має не діяльність на перетворення речей та природи, а та взаємодія між індивідами, яку Девід Белл правдиво називає «грою між людьми» [Иноземцев, 2000: 51-52].

Як вважає Владислав Іноземцев, сьогоднішнє становище, коли більша частина населення змушена працювати, а не творити (тобто реалізовувати себе не виходячи із внутрішніх бажань та захоплень, а через причину «створених обставин», в ім'я поліпшення матеріального добробуту) у найближчий час зміниться. В. Іноземцев пише: «Праця розглядається нами як свідома діяльність, основою якої є спонукальний мотив, який пов'язаний із задоволенням матеріальних потреб людини. На відміну від праці, творчість представлена більш високим та досконалим типом діяльності та її спонукальна мотивованість сполучена з внутрішніми потребами особистості, прагненням до самореалізації, до збільшення своїх здібностей і талантів, спроможностей та знань. Як здатність людини до створення нового, її прагнення до діяльності, не мотивованої унітарними потребами, творчість існувала завжди, хоча як господарський феномен, вона не була відома ні архаїчному, ні індустріальному суспільству [Иноземцев, 2000: 52-53]».

III. Формування вмінь на рівні практики та стратегій інтегративної діяльності.

На цій умові акцентує увагу у своїх дослідженнях Олег Базалук [Базалук, 2015]. Він підкреслює особливості формування тактичного та стратегічного мислення у студентів вищих навчальних закладів. Базалук вважає, що більша частина сучасних проблем у масштабах цивілізації Землі відбувається через неналежне відношення до розвитку стратегічного мислення у молоді. У своїй більшості, як показує аналіз О. Базалука, випускники освітніх закладів виходять у самостійне життя із розумінням тактичних завдань: знайти добре оплачувану роботу, залишити після себе нащадків, створити сім'ю тощо. На запитання, а що далі, навіщо потрібно здійснювати подібні дії, та саме головне, у якій діяльності молода людина планує реалізувати себе у подальші роки життя ці запитання залишаються без відповідей.

В основі класифікації принципу діяльнісної направленості закладені [Новиков, 2008]:

- вміння здійснювати інтегративну професійну діяльність як вищу ланку досвіду особи;

- знання, які визначають діяльнісну направленість особистості;

- майстерність на рівні тактики та стратегії професійної діяльності.

Таким чином, ідея гуманізації освіти в Україні при якісній систематизації та більш глибокому розумінні здійснена на практиці. Втілення ідеї гуманізації у педагогічних впливах на учнів та студентів, призводять до наступного:

- досконалості світоглядних позицій студентів;

- укріпленню духовної складової внутрішнього світу студентів;

- підвищенню професійних якостей, а саме - поваги до права;

- розширенню власних уявлень та настанов, котрі базуються на сучасних правових цінностях суспільства;

- компетенції, достатньої для захисту прав та законних інтересів особистості й правомірної реалізації громадянської позиції. 


\section{Висновки}

Таким чином, з позицій діяльнісного підходу нами досліджено зв'язок свідомості і правової діяльності. Ми розглянули структуру діяльнісної направленості правової освіти, що поглиблює вивчення і подальшу розробку космічного права. Космічні технології займають важливе місце в економічному розвитку України. Тому, знання правових засад використання цих технологій у внутрішньодержавній і міждержавній діяльності забезпечує глибше розуміння ролей, які космос, технологія та право грають у глобалізованому світі. Знання космічного права та розвиток правової освіти в Україні сприяе налагодженню міжнародній співпраці в дослідженні та використанні космосу.

\section{Література}

Базалук, Олег. Современное понимание философии образования. Философская мысль. № 4, 2015: 248-271.

Гаджиева, Патимат. Интерактивные методы в правовом образовании учащихся: дисс. ... канд. пед. наук: спец. 13.00.01 Махачкала, 2005.

Иноземцев, Владислав. Современное постиндустриальное общество: природа, противоречия, перспективы. Москва: Логос, 2000.

Концепція розвитку вищої юридичної освіти в Україні. Юридичний журнал. 11, 2009.

Новиков, Александр. Постиндустриальное образование. Москва: Издательство «Эгвес», 2008.

Фіцула, М. М. Правове виховання учнів. Київ: Інститут змісту і методів навчання, 1997.

Berehova, Halyna. The Philosophy of Unity and Development of Harmony as an Option of the Anthrocosmic World View. Philosophy and Cosmology. Volume 18, 2017: 104-111.

Education Curriculum on Space Law. United Nations, March 2014. http://www.unoosa.org/ pdf/publications/st_space_064E.pdf

Fatkhutdinov, Vasyl H., and Oleg Bazaluk. The Importance of the Brain Neuro-Programming Technologies in National and Regional Security Strategies. Philosophy and Cosmology, Volume 20, 2018: 74-82. http://doi.org/10.29202/phil-cosm/20/6

Naumenko, Raisa. Management for the Society of the Future: New Trends in the Training for Civil Servants in Ukraine. Philosophy and Cosmology. Volume 19, 2017: 117-125.

Oleksenko, Roman and Lidiia Fedorova. Homo Economicus as the Basis of "Asgardia" Nation State in Space: Perspective of Educational Technologies. Future Human Image. Volume 7, 2017: 113-119.

\section{References}

Bazaluk, Oleh. Sovremennoe ponymanye fylosofyy obrazovanyia. Fylosofskaia mbisl. № 4, 2015: 248-271.

Hadzhyeva, Patymat. Ynteraktyvnble metodbl v pravovom obrazovanyy uchashchykhsia: dyss. ... kand. ped. nauk: spets. 13.00.01 Makhachkala, 2005.

Ynozemtsev, Vladyslav. Sovremennoe postyndustryalnoe obshchestvo: pryroda, protyvorechyia, perspektyvbl. Moskva: Lohos, 2000.

Kontseptsiia rozvytku vyshchoi yurydychnoi osvity v Ukraini. Yurydychnyi zhurnal. 11, 2009.

Novykov, Aleksandr. Postyndustryalnoe obrazovanye. Moskva: Yzdatelstvo «Эhves», 2008.

Fitsula, M. M. Pravove vykhovannia uchniv. Kyiv: Instytut zmistu i metodiv navchannia, 1997. 
Berehova, Halyna. The Philosophy of Unity and Development of Harmony as an Option of the Anthrocosmic World View. Philosophy and Cosmology. Volume 18, 2017: 104-111.

Education Curriculum on Space Law. United Nations, March 2014. http://www.unoosa.org/ pdf/publications/st_space_064E.pdf

Fatkhutdinov, Vasyl H., and Oleg Bazaluk. The Importance of the Brain Neuro-Programming Technologies in National and Regional Security Strategies. Philosophy and Cosmology, Volume 20, 2018: 74-82. http://doi.org/10.29202/phil-cosm/20/6

Naumenko, Raisa. Management for the Society of the Future: New Trends in the Training for Civil Servants in Ukraine. Philosophy and Cosmology. Volume 19, 2017: 117-125.

Oleksenko, Roman and Lidiia Fedorova. Homo Economicus as the Basis of "Asgardia" Nation State in Space: Perspective of Educational Technologies. Future Human Image. Volume 7, 2017: 113-119. 